DOI https://doi.org/10.18551/rjoas.2018-09.62

\title{
THE CORRELATION BETWEEN GROWTH CHARACTERS AND YIELD OF SHALLOT (ALLIUM ASCALONICUM L.) DUE TO THE APPLICATION OF NITROGEN, PHOSPHATE AND POTASSIUM FERTILIZERS
}

\author{
Susilawati* ${ }^{*}$ Ammar Muhammad, Kurnianingsih Astuti, Irmawati \\ Department of Agronomy, Faculty of Agriculture, University of Sriwijaya
}

\author{
Adhistia Yoanna, Yuniar Fajri \\ Department of Agroecotechnology, Faculty of Agriculture, University of Sriwijaya \\ *E-mail: susilawati@fp.unsri.ac.id
}

\begin{abstract}
The research was aimed to evaluate the correlation between growth characters and yield components of shallot (Allium ascalonicum L.) on several dosages of nitrogen, phosphate and potassium fertilizers. It was conducted on experimental farm and laboratory of Plant Physiology of Department of Agronomy Faculty of Agriculture, University of Sriwijaya in 2018. The research was consisted of two experiments and each experiment used Block Randomized Design with 3 replicates. First experiment was the combination of nitrogen $(\mathrm{N})$ and phosphate $(P)$ application, while second experiment was the combination between $N$ and potassium (K). Same dosages of $\mathrm{N}$ fertilizer were used for both experiments consisting of N1 $=100 \mathrm{~kg} \mathrm{ha}^{-1} ; \mathrm{N}_{2}=150 \mathrm{~kg} \mathrm{ha}^{-1} ; \mathrm{N}_{3}=200 \mathrm{~kg} \mathrm{ha}^{-1} ;$ and $\mathrm{N}_{4}=250 \mathrm{~kg} \mathrm{ha}^{-1}$. Four dosages of $P$ fertilizer was applied in the first experiment consisting of $P_{1}=160 \mathrm{~kg} \mathrm{ha}^{-1} ; P_{2}=220 \mathrm{~kg} \mathrm{ha}^{-1}$; $\mathrm{P}_{3}=280 \mathrm{~kg} \mathrm{ha}^{-1}$; and $\mathrm{P}_{4}=330 \mathrm{~kg} \mathrm{ha}^{-1}$. While $\mathrm{K}$ fertilizer dosages in second experiment were $\mathrm{K}_{1}=50 \mathrm{~kg} \mathrm{ha}^{-1} ; \mathrm{K}_{2}=100 \mathrm{~kg} \mathrm{ha}^{-1} ; \mathrm{K}_{3}=150 \mathrm{~kg} \mathrm{ha}^{-1}$; and $\mathrm{K}_{4}=200 \mathrm{~kg} \mathrm{ha}^{-1}$. Results showed that positive significant correlation was found between vegetative characters and generative characters in both experiments such as between plant height and shallot bulb number, and between total bulbs dry weight per clump and bulb dry weight. The correlation between tiller number per clump and bulb number per clump was only resulted from first experiment. The highest bulb dry weight per clump was resulted from the combination of $150 \mathrm{~kg} \mathrm{~N}^{-1}$ and $160 \mathrm{~kg} \mathrm{P} \mathrm{ha}^{-1}$ and combination of $200 \mathrm{~kg} \mathrm{~N} \mathrm{ha}^{-1}$ and $200 \mathrm{~kg} \mathrm{~K} \mathrm{ha}^{-1}$.
\end{abstract}

\section{KEY WORDS}

Nitrogen fertilizer, phosphate fertilizer, potassium fertilizer, shallot.

Horticulture development in Indonesia has been prioritizing on two commodities, chilli pepper and shallot, since these two commodities not only become basic food ingredients but also have a significant role in affecting inflation in Indonesia. Shallot is one of the leading vegetable commodities that have been intensively cultivated by farmers. It is categorized as complementary spices utilized as food seasoning and traditional medicine. This commodity is also considered as a source of income and employment opportunities that contribute significantly to regional economic development. The prospect of Indonesian shallot development is quite promising since Indonesia is one of shallot exporters in the world. According to data from Food and Agriculture Organization (FAO), Indonesia was ranked in fourth position as shallot exporters after New Zealand, France and Holland, and ranked first among ASEAN countries in the period of 2010 to 2014 (Agricultural Research and Development Agency, 2005).

Based on the data from Center for Agricultural Data and Information (2016), there were 4 provinces of shallot production center in Indonesia considering the average yield from 2011 to 2015. They were Central Java, East Java, West Java and West Nusa Tenggara. These provinces contributed around $85.33 \%$ of shallot total average production in Indonesia. The largest was Central Java with $40.59 \%$ and average production of 432,813 tons. East Java 
contributed $23.16 \%$ with 246,927 tons per year. West Java and West Nusa Tenggara contributed $11.10 \%$ and $10.48 \%$ respectively. The rest of $14.67 \%$ was from other provinces.

Central Statistics Agency of South Sumatra (2015) stated that total shallot production in South Sumatra was 150 tons in 2014, decreasing for about 67 tons (30.87\%) compared to 2013. The decline in production was caused by a decrease in harvest area and decreased productivity. During 2014, shallot production area in South Sumatra was only in four regencies consisting of Ogan Komering Ulu (OKU), Muara Enim, Musi Rawas and South OKU with 65, 18, 65, and 2 tons of production respectively.

Agriculture intensification through either organic or inorganic fertilizing was among the efforts for increasing shallot production in South Sumatra. Shallot is a nutrient sensitive plant where the symptoms would immediately appear due to both deficiency and excess of nutrients. Many studies of fertilizer application on shallot plant has shown good results. A study by Deden (2014) reported that urea application with the dosage of $200 \mathrm{~kg} \mathrm{ha}^{-1}$ or equivalent to $80 \mathrm{~kg} \mathrm{~N}^{-1}$ significantly affected the average plant height. Sumarni et al. (2012) added that the application of $120 \mathrm{~kg} \mathrm{P}_{2} \mathrm{O}_{5}$ ha $^{-1}$ would result the highest bulb fresh weight and bulb dry weight compared to other treatments with 35.02 and $25 \mathrm{~g}$ per plant respectively. Highest bulb dry weight was also resulted by the combination of $250 \mathrm{~kg} \mathrm{~N} \mathrm{ha}^{-1}$ and $150 \mathrm{~kg} \mathrm{~K} \mathrm{ha}^{-1}$ with $64.69 \mathrm{~g}$ per clump as reported by Napitupulu and Winarno (2010). Furthermore, the dosage of $100 \mathrm{~kg} \mathrm{~K} \mathrm{ha}^{-1}$ would increase bulb diameter, fresh weight per bulb and dry weight per bulb (Uke et al., 2015).

Thus, this research was aimed to evaluate the application of several dosages of $\mathrm{N}, \mathrm{P}$, and $\mathrm{K}$ fertilizers on growth and yield of shallot (Allium ascalonicum $\mathrm{L}$.).

\section{METHODS OF RESEARCH}

The research was conducted in experimental farm and laboratory of plant physiology of Department of Agronomy, Faculty of Agriculture, University of Sriwijaya in 2018. The research was consisted of two sets of experiments and both used Block Randomized Design with 3 replicates. First experiment was the combination of $\mathrm{N}$ and $\mathrm{P}$ fertilizer, while the second was the combination of $\mathrm{N}$ and $\mathrm{K}$ fertilizer. Same dosages of $\mathrm{N}$ fertilizer were applied in both experiments consisting of $N_{1}=100 \mathrm{~kg} \mathrm{ha}^{-1} ; N_{2}=150 \mathrm{~kg} \mathrm{ha}^{-1} ; N_{3}=200 \mathrm{~kg} \mathrm{ha}^{-1}$; and $N_{4}=250$ $\mathrm{kg} \mathrm{ha}^{-1}$. Dosages of $P$ fertilizer in first experiment consisted of 4 levels: $P_{1}=160 \mathrm{~kg} \mathrm{ha}^{-1} ; \mathrm{P}_{2}=$ $220 \mathrm{~kg} \mathrm{ha}{ }^{-1} ; P_{3}=280 \mathrm{~kg} \mathrm{ha}^{-1} ;$ and $\mathrm{P}_{4}=330 \mathrm{~kg} \mathrm{ha}^{-1}$. While $\mathrm{K}$ fertilizer dosages in second experiment consisted of $\mathrm{K}_{1}=50 \mathrm{~kg} \mathrm{ha}^{-1} ; \mathrm{K}_{2}=100 \mathrm{~kg} \mathrm{ha}^{-1} ; \mathrm{K}_{3}=150 \mathrm{~kg} \mathrm{ha}^{-1}$; and $\mathrm{K}_{4}=200 \mathrm{~kg}$ $\mathrm{ha}^{-1}$.

Shallot bulb of Bima variety from Central Java weighed around 4 to 6 grams was used as plant material. The bulb was first soaked in fungicide solution containing Azoxystrobin and Difenoconazole for about 15 minutes then was cut at the size of $1 / 3$ of bulb length. The bulb then was planted about $3 \mathrm{~cm}$ of depth on the mix of alluvial soil and manure with the ratio of $2: 1(\mathrm{v}: \mathrm{v})$ in a $20 \mathrm{~cm} \times 40 \mathrm{~cm}$ of polybag. Each polybag contained about $10 \mathrm{~kg}$ of planting media with the height media of $23 \mathrm{~cm}$. The fertilizers were applied based on the treatments and the application was carried out twice. Half dosage was first applied 10 days after planting, and another half dosage was given 30 days after planting.

The parameters observed consisted of plant height, leaf number per clump, tiller number per clump, bulb number per clump, fresh weight per bulb, total bulb fresh weight per clump, bulb dry weight, total bulb dry weight per clump, and leaf chlorophyll. Leaf chloropyll was measured using a destructive method (Hall and Rao, 1987). It was carried out by extracting about $0.25 \mathrm{~g}$ of leaf powder with $80 \%$ acetone. The dissolved chlorophyll solution then was filtered using Whatman filter paper and was put on spectrophotometer with 645 and $663 \mathrm{~nm}$ wavelength to determine the absorbents. Total chlorophyll content was calculated by using the formula below:

$$
\text { Total chlorophyll }=(17.3 \times \text { A645) }+(7.18 \times A 663) \mathrm{mg} / \mathrm{l}
$$


The analysis of leaf chlorophyll was conducted in the laboratory of plant physiology in Department of Agronomy, Faculty of Agriculture, University of Sriwijaya.

Shallot bulbs were harvested at 60 days after planting. During harvest, fresh bulbs were first weighed and then were air-dried for 7 days which later were weighed to obtain the data of dry weight per bulb.

\section{RESULTS AND DISCUSSION}

Growth characters. The application of $\mathrm{N}$ and $\mathrm{P}$ fertilizer showed different response in the parameters of plant height, leaf number and tiller number. The highest result for plant height was obtained from $\mathrm{N}_{2} \mathrm{P}_{1}$ treatment with $40.64 \mathrm{~cm}$ and the lowest was $32.10 \mathrm{~cm}$ in $\mathrm{N}_{2} \mathrm{P}_{3} . \mathrm{N}_{1} \mathrm{P}_{1}$ treatment resulted the highest number of leaf with 32.56 of leaves, while the lowest was 22.46 in $\mathrm{N}_{2} \mathrm{P}_{3}$. The highest tiller number was found in $\mathrm{N}_{1} \mathrm{P}_{1}$ with 6.74 tillers and the lowest was in $\mathrm{N}_{1} \mathrm{P}_{3}$ with 4.35 tillers (Table 1).

Table 1 - The application of $\mathrm{N}$ and $\mathrm{P}$ fertilizer on growth characters of shallot

\begin{tabular}{|c|c|c|c|c|}
\hline \multirow{2}{*}{$\mathrm{N}$ treatments } & \multicolumn{4}{|c|}{$\mathrm{P}$ treatments } \\
\hline & $\mathrm{P}_{1}$ & $\mathrm{P}_{2}$ & $\mathrm{P}_{3}$ & $\mathrm{P}_{4}$ \\
\hline & \multicolumn{4}{|c|}{ Plant height $(\mathrm{cm})$} \\
\hline $\mathrm{N}_{1}$ & $40.32 \pm 0.47$ & $36.07 \pm 4.49$ & $31.31 \pm 9.45$ & $33.07 \pm 4.98$ \\
\hline $\mathrm{N}_{2}$ & $40.64 \pm 4.34$ & $33.59 \pm 1.24$ & $32.10 \pm 4.03$ & $35.53 \pm 9.95$ \\
\hline $\mathrm{N}_{3}$ & $36.00 \pm 4.16$ & $32.90 \pm 7.47$ & $35.50 \pm 3.33$ & $36.54 \pm 3.29$ \\
\hline \multirow[t]{2}{*}{$\mathrm{N}_{4}$} & $34.89 \pm 6.02$ & $33.10 \pm 6.63$ & $32.92 \pm 0.80$ & $39.34 \pm 3.03$ \\
\hline & \multicolumn{4}{|c|}{ Leaf number } \\
\hline $\mathrm{N}_{1}$ & $32.56 \pm 2.74$ & $25.54 \pm 3.79$ & $21.59 \pm 4.18$ & $26.69 \pm 3.73$ \\
\hline $\mathrm{N}_{2}$ & $29.43 \pm 5.46$ & $25.20 \pm 3.56$ & $22.46 \pm 4.99$ & $26.63 \pm 10.28$ \\
\hline $\mathrm{N}_{3}$ & $26.19 \pm 3.37$ & $25.98 \pm 8.79$ & $25.89 \pm 2.80$ & $25.74 \pm 2.80$ \\
\hline \multirow[t]{2}{*}{$\mathrm{N}_{4}$} & $24.67 \pm 6.89$ & $25.57 \pm 2.39$ & $25.54 \pm 1.64$ & $25.28 \pm 3.86$ \\
\hline & \multicolumn{4}{|c|}{ Tiller number } \\
\hline $\mathrm{N}_{1}$ & $6.74 \pm 1.13$ & $5.76 \pm 1.12$ & $4.35 \pm 0.28$ & $5.76 \pm 0.33$ \\
\hline $\mathrm{N}_{2}$ & $5.72 \pm 0.64$ & $5.37 \pm 0.18$ & $5.06 \pm 0.99$ & $5.31 \pm 0.32$ \\
\hline $\mathrm{N}_{3}$ & $5.70 \pm 0.46$ & $6.65 \pm 0.22$ & $5.44 \pm 1.25$ & $5.98 \pm 1.12$ \\
\hline $\mathrm{N}_{4}$ & $5.35 \pm 0.26$ & $5.44 \pm 0.40$ & $5.59 \pm 1.00$ & $5.31 \pm 0.42$ \\
\hline
\end{tabular}

Plant responses to the application of $\mathrm{N}$ and $\mathrm{K}$ fertilizer were also different as seen in plant length, leaf number and tiller number (Table 2). The treatment with highest plant length was $\mathrm{N}_{2} \mathrm{~K}_{4}$ with $42.08 \mathrm{~cm}$ and the lowest was $32.34 \mathrm{~cm}$ in $\mathrm{N}_{4} \mathrm{~K}_{3}$. Plant with most leaf number was found in $\mathrm{N}_{1} \mathrm{~K}_{1}$ and $\mathrm{N}_{4} \mathrm{~K}_{2}$ with 34 leaves, while the least was in $\mathrm{N}_{4} \mathrm{~K}_{1}$ with 22 leaves. Highest tiller number was in $\mathrm{N}_{2} \mathrm{~K}_{4}$ with 6.74 tillers and the lowest was in $\mathrm{N}_{4} \mathrm{~K}_{3}$ with 4.19 tillers.

Tabel 2 - The application of $\mathrm{N}$ and $\mathrm{K}$ fertilizer on growth characters of shallot

\begin{tabular}{|c|c|c|c|c|}
\hline \multirow{2}{*}{$\mathrm{N}$ treatments } & \multicolumn{4}{|c|}{$\mathrm{K}$ treatments } \\
\hline & $\mathrm{K}_{1}$ & $\mathrm{~K}_{2}$ & $\mathrm{~K}_{3}$ & $\mathrm{~K}_{4}$ \\
\hline & \multicolumn{4}{|c|}{ Plant height $(\mathrm{cm})$} \\
\hline $\mathrm{N}_{1}$ & $39.91 \pm 5.70$ & $38.04 \pm 2.23$ & $33.88 \pm 2.47$ & $34.76 \pm 1.87$ \\
\hline $\mathrm{N}_{2}$ & $39.88 \pm 3.15$ & $38.67 \pm 0.88$ & $40.38 \pm 1.67$ & $42.08 \pm 2.46$ \\
\hline $\mathrm{N}_{3}$ & $38.78 \pm 5.17$ & $36.53 \pm 2.57$ & $34.83 \pm 5.84$ & $38.57 \pm 2.73$ \\
\hline \multirow[t]{2}{*}{$\mathrm{N}_{4}$} & $39.56 \pm 1.77$ & $38.53 \pm 4.47$ & $32.34 \pm 10.88$ & $40.76 \pm 3.88$ \\
\hline & \multicolumn{4}{|c|}{ Leaf number } \\
\hline $\mathrm{N}_{1}$ & $34 \pm 12.08$ & $30 \pm 9.22$ & $25 \pm 8.46$ & $23 \pm 4.55$ \\
\hline $\mathrm{N}_{2}$ & $33 \pm 8.19$ & $23 \pm 5.01$ & $29 \pm 13.50$ & $30 \pm 6.29$ \\
\hline $\mathrm{N}_{3}$ & $25 \pm 7.84$ & $23 \pm 6.17$ & $29 \pm 13.12$ & $31 \pm 8.28$ \\
\hline \multirow[t]{2}{*}{$\mathrm{N}_{4}$} & $22 \pm 3.91$ & $34 \pm 9.38$ & $31 \pm 8.06$ & $32 \pm 11.24$ \\
\hline & \multicolumn{4}{|c|}{ Tiller number } \\
\hline $\mathrm{N}_{1}$ & $5.59 \pm 1.07$ & $5.54 \pm 0.42$ & $5.54 \pm 0.92$ & $4.94 \pm 0.15$ \\
\hline $\mathrm{N}_{2}$ & $6.61 \pm 0.67$ & $5.19 \pm 0.67$ & $5.20 \pm 0.61$ & $5.70 \pm 1.28$ \\
\hline $\mathrm{N}_{3}$ & $5.39 \pm 0.73$ & $4.52 \pm 0.50$ & $4.89 \pm 1.27$ & $5.39 \pm 0.72$ \\
\hline $\mathrm{N}_{4}$ & $5.56 \pm 0.80$ & $5.02 \pm 0.59$ & $4.19 \pm 1.00$ & $5.33 \pm 0.38$ \\
\hline
\end{tabular}


The combination of $\mathrm{N}$ with $\mathrm{P}$ and $\mathrm{K}$ with the highest plant height and the most leaf number was obtained in the same $\mathrm{N}$ dosages with $150 \mathrm{~kg} \mathrm{ha}^{-1}$ and $100 \mathrm{~kg} \mathrm{ha}^{-1}$, respectively. While for tiller number, best results were obtained in the combination of $P$ with $100 \mathrm{~kg} \mathrm{ha}^{-1} \mathrm{~N}$ dosage and in the combination of $\mathrm{K}$ with $150 \mathrm{~kg} \mathrm{ha}^{-1}$ of $\mathrm{N}$ dosage (Table 2). Pramitasari et al. (2016) reported that $\mathrm{N}$ supply would affect the growth, appearance, color, and yield of plants. The application of $\mathrm{N}$ would initiate the green color as it was the structural element of chlorophyll which later contributed in photosynthesis.

Yield components. Table 3 shows the effect of $N$ and $P$ application on yield components. It was resulted that bulb number per clump was around $5.78-8.42$ bulbs. The highest number was obtained from $\mathrm{N}_{1} \mathrm{P}_{1}$ and the lowest was from $\mathrm{N}_{2} \mathrm{P}_{3}$. Similar to this, Suwandi et al. (2015) reported that Katumi variety shallot could result 9 bulbs per clump, while Bima variety resulted $5-8$ bulbs. So in this case, the number of both bulbs and tillers was likely influenced by the genetic factor. Basuki (2009) added that the number of either bulbs or tillers would be affected by the size of planting bulb. The bigger bulb planted, the smaller the tiller number.

The combination of $100 \mathrm{~kg} \mathrm{ha}^{-1} \mathrm{~N}$ fertilizer and $160 \mathrm{~kg} \mathrm{ha}^{-1} \mathrm{P}$ fertilizer $\left(\mathrm{N}_{1} \mathrm{P}_{1}\right)$ showed the highest results for total bulb fresh weight per clump and fresh weight per bulb with $9.81 \mathrm{~g}$ and $8.53 \mathrm{~g}$, respectively. It was assumed that the mix of planting media between soil and manure had provided sufficient nutrients. Sumarni et al. (2012) reported that excess P application (more than $180 \mathrm{~kg} \mathrm{ha}^{-1}$ ) would decrease fresh weight per bulb due to excess $\mathrm{P}$ in soil abrupting soil nutrients balance. $\mathrm{N}_{1} \mathrm{P}_{1}$ treatment also resulted the highest total bulb dry weight per clump with $49.38 \mathrm{~g}$. However, the highest dry weight per bulb was obtained from the combination of $150 \mathrm{~kg} \mathrm{ha}^{-1} \mathrm{~N}$ fertilizer and $160 \mathrm{~kg} \mathrm{ha}^{-1} \mathrm{P}$ fertilizer $\left(\mathrm{N}_{2} \mathrm{P}_{1}\right)$ with $6.43 \mathrm{~g}$. The application of $P$ with the dosage higher than $120 \mathrm{~kg} \mathrm{ha}^{-1}$ would not likely increase shallot yield since excess $P$ in soil would surpress micro nutrients availability (Sumarrni et al., 2012).

Table 3 - The application of $\mathrm{N}$ and $\mathrm{P}$ fertilizer on yield components of shallot

\begin{tabular}{|c|c|c|c|c|}
\hline \multirow{2}{*}{$\mathrm{N}$ treatments } & \multicolumn{4}{|c|}{$\mathrm{P}$ treatments } \\
\hline & $\mathrm{P}_{1}$ & $\mathrm{P}_{2}$ & $\mathrm{P}_{3}$ & $\mathrm{P}_{4}$ \\
\hline & \multicolumn{4}{|c|}{ Bulb number per clump } \\
\hline $\mathrm{N}_{1}$ & $8.42 \pm 1.52$ & $6.88 \pm 0.76$ & $5.89 \pm 0.70$ & $7.22 \pm 1.38$ \\
\hline $\mathrm{N}_{2}$ & $8.11 \pm 1.84$ & $6.78 \pm 0.84$ & $5.78 \pm 1.50$ & $7.67 \pm 2.52$ \\
\hline $\mathrm{N}_{3}$ & $6.89 \pm 2.34$ & $7.67 \pm 1.53$ & $6.89 \pm 2.01$ & $7.33 \pm 2.33$ \\
\hline \multirow[t]{2}{*}{$\mathrm{N}_{4}$} & $6.76 \pm 0.66$ & $7.11 \pm 1.90$ & $7.67 \pm 1.52$ & $7.11 \pm 1.69$ \\
\hline & \multicolumn{4}{|c|}{ Total bulb fresh weight per clump $(\mathrm{g})$} \\
\hline $\mathrm{N}_{1}$ & $69.81 \pm 12.25$ & $44.27 \pm 12.80$ & $30.12 \pm 21.72$ & $34.88 \pm 12.91$ \\
\hline $\mathrm{N}_{2}$ & $63.07 \pm 4.83$ & $36.92 \pm 13.40$ & $39.86 \pm 16.60$ & $53.67 \pm 31.91$ \\
\hline $\mathrm{N}_{3}$ & $42.76 \pm 21.40$ & $48.39 \pm 32.03$ & $52.37 \pm 13.81$ & $37.84 \pm 17.73$ \\
\hline \multirow[t]{2}{*}{$\mathrm{N}_{4}$} & $48.45 \pm 25.49$ & $47.00 \pm 12.24$ & $42.95 \pm 14.31$ & $51.21 \pm 22.98$ \\
\hline & \multicolumn{4}{|c|}{ Fresh weight per bulb $(\mathrm{g})$} \\
\hline $\mathrm{N}_{1}$ & $8.53 \pm 0.32$ & $6.96 \pm 1.02$ & $4.96 \pm 3.45$ & $4.65 \pm 1.55$ \\
\hline $\mathrm{N}_{2}$ & $8.02 \pm 1.69$ & $5.66 \pm 2.21$ & $6.95 \pm 1.68$ & $6.44 \pm 2.93$ \\
\hline $\mathrm{N}_{3}$ & $5.92 \pm 1.74$ & $6.11 \pm 3.78$ & $8.04 \pm 1.04$ & $5.47 \pm 3.31$ \\
\hline \multirow[t]{2}{*}{$\mathrm{N}_{4}$} & $7.04 \pm 3.55$ & $7.38 \pm 2.11$ & $6.62 \pm 0.38$ & $7.12 \pm 2.04$ \\
\hline & \multicolumn{4}{|c|}{ Total bulb dry weight per clump $(\mathrm{g})$} \\
\hline $\mathrm{N}_{1}$ & $49.38 \pm 7.78$ & $27.39 \pm 10.93$ & $18.72 \pm 13.47$ & $25.95 \pm 14.52$ \\
\hline $\mathrm{N}_{2}$ & $49.26 \pm 0.96$ & $20.65 \pm 11.42$ & $24.19 \pm 13.62$ & $36.32 \pm 26.35$ \\
\hline $\mathrm{N}_{3}$ & $28.95 \pm 14.20$ & $34.17 \pm 21.99$ & $33.91 \pm 16.95$ & $25.81 \pm 14.38$ \\
\hline \multirow[t]{2}{*}{$\mathrm{N}_{4}$} & $29.81 \pm 17.80$ & $29.82 \pm 11.90$ & $23.83 \pm 7.69$ & $34.79 \pm 13.24$ \\
\hline & \multicolumn{4}{|c|}{ Dry weight per bulb $(\mathrm{g})$} \\
\hline $\mathrm{N}_{1}$ & $6.08 \pm 0.46$ & $3.90 \pm 1.46$ & $3.02 \pm 2.30$ & $3.02 \pm 1.16$ \\
\hline $\mathrm{N}_{2}$ & $6.43 \pm 1.96$ & $2.89 \pm 1.16$ & $3.98 \pm 1.89$ & $4.25 \pm 2.73$ \\
\hline $\mathrm{N}_{3}$ & $3.99 \pm 1.41$ & $4.21 \pm 2.35$ & $4.49 \pm 1.10$ & $3.67 \pm 2.59$ \\
\hline $\mathrm{N}_{4}$ & $4.27 \pm 2.39$ & $4.60 \pm 1.58$ & $3.64 \pm 0.63$ & $4.82 \pm 1.13$ \\
\hline
\end{tabular}

The effect of $\mathrm{N}$ and $\mathrm{K}$ application on yield components is given in Table 4. Based on the results, it was found that bulb number was related to tiller number. Similar to this, a study by Basuki (2009) resulted that bigger bulb would produce less tiller number. The highest total bulb fresh weight per clump and fresh weight per bulb was obtained from the combination of 
$250 \mathrm{~kg} \mathrm{ha} \mathrm{h}^{-1} \mathrm{~N}$ fertilizer and $100 \mathrm{~kg} \mathrm{ha}^{-1} \mathrm{~K}$ fertilizer $\left(\mathrm{N}_{4} \mathrm{~K}_{3}\right)$ with $50.63 \mathrm{~g}$ and $9.14 \mathrm{~g}$, respectively. According to Napitupulu and Winarno (2010), the application of high dosage $\mathrm{N}$ and $\mathrm{K}$ fertilizer would provide enough amount of nutrients to increase fresh weight per bulb. Lower fresh weight per bulb was probably caused by less $\mathrm{N}$ and $\mathrm{K}$ supply for bulb development. Fikri et al. (2015) stated that balance amount of potassium would positively affect assimilate translocation from leaves to the storing organs, including shallot bulbs.

Highest total bulb dry weight per clump was resulted from $\mathrm{N}_{2} \mathrm{~K}_{1}$ treatment with $38.21 \mathrm{~g}$. While for dry weight per bulb, the highest was obtained in $\mathrm{N}_{3} \mathrm{~K}_{4}$ with $6.84 \mathrm{~g}$. It was assumed that the combination of $\mathrm{N}$ fertilizer with lower dosage of $\mathrm{K}$ fertilizer did not affect total dry weight per bulb since high $\mathrm{N}$ dosage would cause a more watery bulb. Napitupulu and Winarno (2015) had reported that the application of high $\mathrm{N}$ dosage fertilizer without $\mathrm{K}$ fertilizer caused the plant become succulent and did not increase plant dry weight.

Table 4 - The application of $\mathrm{N}$ and $\mathrm{K}$ fertilizer on yield components of shallot

\begin{tabular}{|c|c|c|c|c|}
\hline \multirow[t]{2}{*}{$\mathrm{N}$ treatments } & \multicolumn{4}{|c|}{$\mathrm{K}$ treatments } \\
\hline & $\mathrm{K}_{1}$ & $\mathrm{~K}_{2}$ & $\mathrm{~K}_{3}$ & $\mathrm{~K}_{4}$ \\
\hline & \multicolumn{4}{|c|}{ Bulb number per clump } \\
\hline $\mathrm{N}_{1}$ & $6.00 \pm 1.00$ & $5.70 \pm 0.58$ & $5.03 \pm 2.08$ & $6.00 \pm 1.00$ \\
\hline $\mathrm{N}_{2}$ & $6.00 \pm 1.73$ & $5.30 \pm 1.53$ & $6.00 \pm 1.00$ & $6.30 \pm 1.53$ \\
\hline $\mathrm{N}_{3}$ & $6.00 \pm 0.00$ & $4.70 \pm 1.53$ & $5.00 \pm 1.00$ & $5.30 \pm 1.15$ \\
\hline \multirow[t]{2}{*}{$\mathrm{N}_{4}$} & $5.70 \pm 1.53$ & $6.00 \pm 0.00$ & $5.00 \pm 1.00$ & $6.00 \pm 1.00$ \\
\hline & \multicolumn{4}{|c|}{ Total bulb fresh weight per clump $(\mathrm{g})$} \\
\hline $\mathrm{N}_{1}$ & $43.41 \pm 18.64$ & $48.22 \pm 24.15$ & $32.76 \pm 10.48$ & $30.03 \pm 4.19$ \\
\hline $\mathrm{N}_{2}$ & $50.31 \pm 18.87$ & $35.80 \pm 10.52$ & $36.02 \pm 24.88$ & $48.64 \pm 4.58$ \\
\hline $\mathrm{N}_{3}$ & $47.90 \pm 17.97$ & $31.63 \pm 18.34$ & $36.28 \pm 16.98$ & $44.42 \pm 8.65$ \\
\hline \multirow[t]{2}{*}{$\mathrm{N}_{4}$} & $40.87 \pm 6.35$ & $50.63 \pm 13.17$ & $41.72 \pm 5.26$ & $44.17 \pm 15.34$ \\
\hline & \multicolumn{4}{|c|}{ Fresh weight per bulb $(\mathrm{g})$} \\
\hline $\mathrm{N}_{1}$ & $7.66 \pm 2.47$ & $8.56 \pm 3.84$ & $6.18 \pm 1.24$ & $5.32 \pm 0.64$ \\
\hline $\mathrm{N}_{2}$ & $8.30 \pm 1.97$ & $7.20 \pm 1.81$ & $5.99 \pm 3.63$ & $7.93 \pm 2.05$ \\
\hline $\mathrm{N}_{3}$ & $8.15 \pm 3.44$ & $6.61 \pm 2.43$ & $6.38 \pm 1.77$ & $8.91 \pm 1.98$ \\
\hline \multirow[t]{2}{*}{$\mathrm{N}_{4}$} & $8.73 \pm 4.29$ & $9.14 \pm 2.34$ & $8.59 \pm 2.32$ & $7.30 \pm 2.37$ \\
\hline & \multicolumn{4}{|c|}{ Total dry weight per bulb (g) } \\
\hline $\mathrm{N}_{1}$ & $37.50 \pm 13.38$ & $35.70 \pm 14.16$ & $21.76 \pm 8.74$ & $19.40 \pm 5.11$ \\
\hline $\mathrm{N}_{2}$ & $38.21 \pm 15.36$ & $25.67 \pm 12.40$ & $28.38 \pm 14.57$ & $33.42 \pm 0.56$ \\
\hline $\mathrm{N}_{3}$ & $31.04 \pm 15.61$ & $23.60 \pm 8.82$ & $30.26 \pm 16.84$ & $35.30 \pm 7.23$ \\
\hline \multirow[t]{2}{*}{$\mathrm{N}_{4}$} & $25.51 \pm 0.83$ & $33.83 \pm 10.32$ & $31.99 \pm 1.20$ & $35.32 \pm 8.18$ \\
\hline & \multicolumn{4}{|c|}{ Dry weight per bulb $(\mathrm{g})$} \\
\hline $\mathrm{N}_{1}$ & $6.58 \pm 2.27$ & $6.20 \pm 2.60$ & $3.64 \pm 0.63$ & $3.30 \pm 0.32$ \\
\hline $\mathrm{N}_{2}$ & $5.98 \pm 2.07$ & $5.04 \pm 2.84$ & $4.76 \pm 2.43$ & $5.46 \pm 1.59$ \\
\hline $\mathrm{N}_{3}$ & $5.34 \pm 3.47$ & $4.96 \pm 1.19$ & $5.57 \pm 3.32$ & $6.84 \pm 1.34$ \\
\hline $\mathrm{N}_{4}$ & $5.14 \pm 2.05$ & $6.02 \pm 2.52$ & $6.56 \pm 1.21$ & $5.94 \pm 1.99$ \\
\hline
\end{tabular}

Correlation between vegetative characters and yield components. Based on correlation analysis among parameters due to fertilizer combinations treatments (Table 5 and 6), it was resulted that plant height was significantly positive correlated with leaf number and bulb number per clump with $r=0.747$ and $r=0.710$ for $\mathrm{N}$ and $\mathrm{P}$ combination treatments, and $\mathrm{r}=$ 0.678 and $r=0.684$ for $\mathrm{N}$ and $\mathrm{K}$ treatments. Deden (2014) reported that higher plant height and more number of leaves would increase shallot production as seen in bulb number per clump. Rahayu and Berlian (2004) added that well-grown shallot was characterized by having longer and more number of leaves so that it would produce bigger bulbs resulting in higher yield production. Higher plant was believed would produce more photosynthates which later be translocated to the storing organs and would initiate bigger bulb development (Arifin et al., 2014). Leaf number was significantly positive correlated to tiller number, total bulb fresh weight per clump and total bulb dry weight per clump. The more number of shallot leaves, the more photosynthates produced and the more carbohydrates translocated to the storing organs or to other developing organs Khoiroh, 2014).

From $\mathrm{N}$ and $\mathrm{P}$ combination treatments, significant correlations were resulted from plant height to leaf number, bulb number, total bulb dry weight per clump and dry weight per bulb (Table 5). Limbongan and Monde (1999) reported that leaf number of a variety would related 
to bulb number due to more photosynthates produced. More photosynthates would also lead to more tiller number. For leaf number parameter, it was significantly positive correlated to tiller number, bulb number, total bulb fresh weight per clump, total bulb dry weight per clump and dry weight per bulb. While tiller number correlated with bulb number. Shallot plant with more tiller number would also produce more number of bulbs. Similar to this result, Kusmana et al. (2009) reported that Tanduyung shallot variety with the most number of tillers had produced the most number of bulbs. Total bulb fresh weight per clump significantly correlated to total bulb dry weight per clump. Research finding by Mayun (2007) also showed similar result where fresh weight per bulb affected air-dried bulb weight.

Table 5 - Correlation among parameters due to the application of $\mathrm{N}$ and $\mathrm{P}$ fertilizer

\begin{tabular}{|c|c|c|c|c|c|c|c|c|c|}
\hline No & Parameters & $\begin{array}{l}\text { Plant } \\
\text { height }\end{array}$ & $\begin{array}{l}\text { Leaf } \\
\text { number } \\
\text { per } \\
\text { clump }\end{array}$ & $\begin{array}{c}\text { Tiller } \\
\text { number } \\
\text { per } \\
\text { clump }\end{array}$ & $\begin{array}{c}\text { Bulb } \\
\text { number } \\
\text { per } \\
\text { clump }\end{array}$ & $\begin{array}{l}\text { Total bulb } \\
\text { fresh } \\
\text { weight } \\
\text { per clump }\end{array}$ & $\begin{array}{c}\text { Fresh } \\
\text { weight } \\
\text { per bulb }\end{array}$ & $\begin{array}{l}\text { Total bulb } \\
\text { dry } \\
\text { weight } \\
\text { per clump }\end{array}$ & $\begin{array}{c}\text { Dry } \\
\text { weight } \\
\text { per bulb }\end{array}$ \\
\hline 1 & Plant height & 1 & 0.747 & $0.605^{\text {ns }}$ & 0.710 & $0.778^{\mathrm{ns}}$ & $0.600^{\text {ns }}$ & 0.816 & 0.797 \\
\hline 2 & $\begin{array}{l}\text { Leaf number } \\
\text { per clump }\end{array}$ & & 1 & $0.869^{* *}$ & $0.916^{* *}$ & $0.809^{* *}$ & $0.521^{\mathrm{ns}}$ & $0.843^{* *}$ & $0.716^{*}$ \\
\hline 3 & $\begin{array}{l}\text { Tiller number } \\
\text { per clump }\end{array}$ & & & 1 & $0.769^{*}$ & $0.582^{\mathrm{ns}}$ & $0.380^{\mathrm{ns}}$ & $0.591^{\mathrm{ns}}$ & $0.488^{\mathrm{ns}}$ \\
\hline 4 & $\begin{array}{l}\text { Bulb number } \\
\text { per clumo } \\
\text { Total bulb }\end{array}$ & & & & 1 & $0.764^{*}$ & $0.392^{\mathrm{ns}}$ & $0.839^{* *}$ & $0.676^{*}$ \\
\hline 5 & $\begin{array}{l}\text { fresh weight } \\
\text { per clump }\end{array}$ & & & & & 1 & $0.855^{\star *}$ & $0.959^{* *}$ & $0.936^{* *}$ \\
\hline 6 & $\begin{array}{l}\text { Fresh weight } \\
\text { per bulb }\end{array}$ & & & & & & 1 & $0.730^{*}$ & $0.849^{* *}$ \\
\hline 7 & $\begin{array}{l}\text { Total bulb dry } \\
\text { weight per } \\
\text { clump }\end{array}$ & & & & & & & 1 & $0.943^{* *}$ \\
\hline 8 & $\begin{array}{l}\text { Dry weight } \\
\text { per bulb }\end{array}$ & & & & & & & & 1 \\
\hline
\end{tabular}

Table 6 - Correlation among parameters due to the application of $\mathrm{N}$ and $\mathrm{K}$ fertilizer

\begin{tabular}{|c|c|c|c|c|c|c|c|c|c|}
\hline No & Parameters & $\begin{array}{l}\text { Plant } \\
\text { height }\end{array}$ & $\begin{array}{l}\text { Leaf } \\
\text { number } \\
\text { per } \\
\text { clump }\end{array}$ & $\begin{array}{c}\text { Tiller } \\
\text { number } \\
\text { per } \\
\text { clump }\end{array}$ & $\begin{array}{c}\text { Bulb } \\
\text { number } \\
\text { per } \\
\text { clump }\end{array}$ & $\begin{array}{l}\text { Total bulb } \\
\text { fresh } \\
\text { weight } \\
\text { per clump }\end{array}$ & $\begin{array}{c}\text { Fresh } \\
\text { weight } \\
\text { per bulb }\end{array}$ & $\begin{array}{l}\text { Total bulb } \\
\text { dry } \\
\text { weight } \\
\text { per clump }\end{array}$ & $\begin{array}{c}\text { Dry } \\
\text { weight } \\
\text { per bulb }\end{array}$ \\
\hline 1 & Plant height & 1 & $0.678^{\prime}$ & 0.726 & 0.684 & $0.552^{\text {ns }}$ & $0.331^{\text {ns }}$ & $0.464^{\mathrm{ns}}$ & $0.262^{\text {ns }}$ \\
\hline 2 & $\begin{array}{l}\text { Leaf number } \\
\text { per clump }\end{array}$ & & 1 & $0.716^{*}$ & $0.637^{\mathrm{ns}}$ & $0.728^{*}$ & $0.441^{\mathrm{ns}}$ & $0.779^{*}$ & $0.517^{\mathrm{ns}}$ \\
\hline 3 & $\begin{array}{l}\text { Tiller number } \\
\text { per clump }\end{array}$ & & & 1 & $0.628^{\mathrm{ns}}$ & $0.433^{\mathrm{ns}}$ & $0.211^{\mathrm{ns}}$ & $0.322^{\mathrm{ns}}$ & $0.040^{\mathrm{ns}}$ \\
\hline 4 & $\begin{array}{l}\text { Bulb number } \\
\text { per clumo } \\
\text { Total bulb }\end{array}$ & & & & 1 & $0.523^{\mathrm{ns}}$ & $0.132^{\mathrm{ns}}$ & $0.343^{\text {ns }}$ & $0.0 \overline{1}^{\text {ns }}$ \\
\hline 5 & $\begin{array}{l}\text { fresh weight } \\
\text { per clump }\end{array}$ & & & & & 1 & $0.831^{\text {** }}$ & $0.855^{\star *}$ & $0.712^{*}$ \\
\hline 6 & $\begin{array}{l}\text { Fresh weight } \\
\text { per bulb }\end{array}$ & & & & & & 1 & $0.665^{\mathrm{ns}}$ & $0.772^{*}$ \\
\hline 7 & $\begin{array}{l}\text { Total bulb dry } \\
\text { weight per } \\
\text { clump }\end{array}$ & & & & & & & 1 & $0.887^{* *}$ \\
\hline 8 & $\begin{array}{l}\text { Dry weight } \\
\text { per bulb }\end{array}$ & & & & & & & & 1 \\
\hline
\end{tabular}

Table 6 shows significant positive correlation was found between growth parameters, such as plant height and leaf number, to shallot yield due to the application of $\mathrm{N}$ and $\mathrm{K}$ fertilizers. However no significant response was resulted from all parameters for both growth and yield characters based on the analysis of variance (data not shown). Positive correlation 
was found between plant height and leaf number since shallot height was vertically measured the highest leaf so that it assumed that plant height would increase following the increase in leaf number. The increase in leaf number would benefit the plant regarding the enhanced sunlight interception and $\mathrm{CO}_{2}$ fixation for photosynthesis (Ni'am and Bintari, 2017).

Leaf number also significantly positive correlated with tiller number, total bulb fresh weight per clump, and total bulb dry weight per clump. It was clearly understandable that plant with more tiller number would also have more leaf number leading to the improved in photosynthetic rate resulting in better accumulation of photosynthates. Similar to this, a study by Eki et al. (2016) resulted that plant fresh and dry weight was increased following the increase in leaf number and leaf area. Bulb dry weight would greatly depended on bulb fresh weight as reported by Yusniwati et al. (2014).

\section{CONCLUSION}

Plant height was significantly positive correlated with bulb number, total bulb dry weight per clump and dry weight per bulb for either $\mathrm{N}$ and $\mathrm{P}$ combinations or $\mathrm{N}$ and $\mathrm{K}$ combinations. Tiller number was only significantly positive correlated with bulb number per clump on $\mathrm{N}$ and $\mathrm{P}$ combinations, and had no correlation for all yield paramaters on $\mathrm{N}$ and $\mathrm{K}$ combinations.

\section{ACKNOWLEDGEMENTS}

Our gratitude to the Rector of Sriwijaya University for the research financial support thorugh the Chief of Sriwijaya University Research Center and Community Service of Universitity of Sriwijaya Institution with Research Competitive Superior Scheme 2018.

\section{REFERENCES}

1. Agricultural Data and Information Center. 2016. The outlook of shallot. Ministry of Agriculture.

2. Agricultural Research and Development Agency. 2005. Prospect and direction of agribusiness shallot development. Jakarta, Dept. of Agriculture.

3. Arifin, M.S., A. Nugroho, and A. Suryanto. 2014. The study of shoot bud length and planted bulb weight on yield of potato (Solanum tuberosum L.) Granola variety. J. Prod. Tan. 2(3): 221-229.

4. Basuki, R.S. 2009. Analysis of Brebes farmers' preference on yield characteristics and quality of local variety of upland and midland shallot. J. Hort. 19(4): 475-482.

5. Center for Agricultural Data and Information. 2015. Production of chilli, chilli pepper, and shallot in 2014. Palembang.

6. Deden. 2014. The effect of nitrogen fertilizer dosages on $\mathrm{N}$ absorbption, growth and yield of several varieties of shallot (Allium ascalonicum L.) J. Agrijati. Vol 27 (1): $40-54$

7. Eki, H.P., W. Tatik, and N. Mochammad. 2016. The effect of Nitrogen fertilizer dosages and plant population on growth and yield of Brassica oleraceae L. J. Prod. Tan. 4(1): 49 56.

8. Fikri, D.A., Nelvia, and Y. Husna. 2015. The application of potassium fertilizer and mix of oil palm empty fruit bunch compost and boiler ash on growth and yield of shallot (Allium ascalonicum L.). J. Agroteknologi 5(2): $1-6$.

9. Hall, D.O and K.K. Rao. 1987. Photosynthesis. 4th ed King's Collage, University of London. London

10. Khoiroh, Y, N. Harijati, and R. Mastuti. 2014. The growth and relation between stomata density and bulb weight on Amorphophallus muelleri Blume and Amorphophallus variabilis Blume. J. Biotropika 2(5): 249-253.

11. Kusmana, R.S. Basuki and H. Kurniawan. 2009. The adaptation analysis of five upland and midland shallot varieties on Brebes low land ecosystem. J. Hort. 19(3): $281-286$.

12. Limbongan, $\mathrm{J}$ and $\mathrm{A}$. Monde. 1999. The application of organic and inorganic fertilizer on growth and yield of shallot cv. Palu. J. Hort. 9(3): 212-219. 
13. Mayun, I.A. 2007. The application of paddy straw mulch and cow manure on growth and yield of shallot in coastal area. Agritrop 26(1): 33-40.

14. Napitupulu, D. and L.Winarto. 2010. The application of $\mathrm{N}$ and $\mathrm{K}$ fertilizers on growth and yield of shallot. J. Hort. 20(1): 27-35.

15. Ni'am, A.M. and S.H Bintari. 2017. The application of legume inoculant and mulch on number of root nodule bacteria and growth of soybean var. Grobogan. J. MIPA 40(2): 8086.

16. Pramitasari, H.E., T. Wardiyati and M. Nawawi. 2016. The effect of $\mathrm{N}$ fertilizer dosages and plant population on growth and yield of Brassica oleraceae I.. J. Prod. Tan. (1): 4956.

17. Rahayu, E. and V.A. N. Berlian. 2004. Shallot. Bogor, Penebar Swadaya.

18. Sumarni, N., R. Rosliani, R.S. Basuki, and Y. Hilman. 2012. The response of shallot to $P$ fertilizer application on several land fertility level (soil P status). J. Hort. 22(2): 130-138.

19. Suwandi, G.A. Sopha, and M.P. Yufdy. 2015. The effectivity of organic and NPK fertilizer application management on growth and yield of shallot. J. Hort. 25: 208-221.

20. Uke, H.Y. Kalwiyah, B. Henry, and S.M. Ichwan. 2015. The effect of bulb size and K dosage on growth and yield of shallot (Allium ascalonicum L.) var. Lembah Palu. Jurnal Agrotekbis 3(6): 655-661.

21. Yusniwati, Y.K., A. Aswaldi, and K. Aulyani. 2014. The effect of shallot seedling age in nursery before transplanting on growth and yield in climate change prone area. Proceedings of National Seminar PERHORTI, Malang 5-7 November 2017. 